\title{
PELA RECONFIGURAÇÃO DOS IMPEDIMENTOS MATRIMONIAIS DECORRENTES DE RELAÇÕES DE PARENTESCO - DO NECESSÁRIO DIÁLOGO ENTRE DIREITO E ANTROPOLOGIA
}

\section{FOR THE RECONFIGURATION OF THE MARRIAGE PROHIBITIONS DUE TO KINSHIP RELATIONS - THE NECESSARY DIALOGUE BETWEEN LAW AND ANTHROPOLOGY}

\author{
${ }^{1}$ Laira Carone Rachid Domith
}

\begin{abstract}
Resumo
A legitimidade dos vínculos socioafetivos enquanto bases para o reconhecimento de relações familiares ainda não foi expressamente prevista em lei, nem suas implicações no regime de impedimentos matrimoniais, que precisam ser reformulados levando em consideração, também, os impactos da reprodução assistida heteróloga sobre constituição de parentesco, tendo em vista a interdição das relações amorosas incestuosas. É imperioso o repensar do conceito de incesto na atualidade, bem como os objetivos de sua interdição. O trabalho aborda a dicotomia entre o dado e o construído, a natureza e a cultura, especificamente em termos de parentesco e proibição da endogamia.
\end{abstract}

Palavras-Chave: Impedimentos matrimoniais; Interdição do incesto; Teoria da Aliança; Parentesco socioafetivo; ascendência genética.

\begin{abstract}
The socioaffective bonds legitimacy while grounds for family relations' acknowledgment has not yet been turned into legislation, neither has its outcomes related to marriage prohibitions' regime, that has to be rebuilt in order to take into consideration, also, the impacts of the heterologous assisted reproduction when it comes to kinship, so as to avoid incestuous romantic relationships. It is of great importance to think over the current definition of incest, as well as the actual aims of its prohibition. The present work approaches the dichotomy between what is given and what is built, the nature and culture, specially when it comes to kinship and endogamy prohibition.
\end{abstract}

Keywords: Marriage prohibitions; Incest interdiction; Bond theory; Socioaffective kinship; Genetic ascendancy.

\footnotetext{
1 Mestre em Direito Público e Evolução Social pela Universidade Estácio de Sá, UNESA - RJ, (Brasil). Professora de Direito de Família da Faculdade Doctum de Juiz de Fora - MG, (Brasil). E-mail : lairarachid@hotmail.com
} 


\section{INTRODUÇÃO}

Há muito o casamento civil deixou de ser o único modelo legítimo de constituição de um núcleo familiar, mas, sem dúvida, ainda continua sendo a forma mais tradicional de fazê-lo, sendo necessária, portanto, uma releitura dos impedimentos matrimoniais compatível com os avanços da Medicina - leia-se Reprodução Humana Assistida - e do chamado Direito de Família Existencial, comprometido com o movimento de constitucionalização do Direito Civil em sua forma plena, abrangendo seus aspectos formal (positivo), substancial e prospectivo, sendo que estes dois últimos possuem o condão de atualizá-lo, diuturnamente, através da busca da promoção e proteção da dignidade da pessoa humana enquanto fundamento do Estado Democrático brasileiro.

Especificamente com relação aos impedimentos matrimoniais decorrentes do parentesco, fundados no Tabu do Incesto, que também geram proibição de constituição de uniões estáveis (e, portanto, proibição de constituição de uniões homoafetivas), faz-se mister repensá-los, bem como o conceito de incesto na contemporaneidade, tendo em vista o reconhecimento doutrinário e jurisprudencial do parentesco socioafetivo e sua desbiologização, sendo este o objetivo do presente estudo.

A moralidade que reveste a interdição do incesto é tão forte que o seu repensar, bem como de seus efeitos jurídicos, torna-se um desafio ${ }^{2}$. Contudo, aqueles impedimentos,

\footnotetext{
${ }^{2}$ Oportunas as seguintes passagens do diálogo entre Cyrulnik e Morin (2012) sobre a natureza humana: MORIN: "- Pois o meio mais certo de assassinar uma ideia é venerá-la. Ao repeti-la infinitamente, a ideia transforma-se em estereótipo, pode-se recitá-la pensando no último jogo França X Inglaterra! Ao contrário disso, fazer viver uma ideia é debatê-la, combatê-la, chegar mesmo a matar certos elementos que a compõem! De todos os modos, sabemos que as causalidades lineares são abusivas: somos nós que as fabricamos por dar ao mundo uma visão redutora e, portanto, repleta de segurança. A partir do instante em que temos uma certeza, a certeza é o melhor dos tranqüilizantes: nos dias atuais, conhecem-se os efeitos dos tranqüilizantes, eles fazem dormir e entorpecem o pensamento. É por isso que uma pequena angústia, um pequeno debate, a condenação à morte de uma ideia, mesmo que em pequenas proporções, permitem criar uma nova ideia, permitem que uma nova teoria viva e nasça" (p. 48-49).

CYRULNIK: “- Com efeito, afirma-se frequentemente que as teorias são muito coerentes para serem honestas, que os cientistas eliminam as flutuações. Quando se faz uma teoria muito coerente, ela está desadaptada do real e não pode mais evoluir. É nas asperezas de uma teoria que se encontra o elemento inesperado que vai permitir inventar uma nova teoria. Retomando o que você disse sobre o mundo da certeza e da incerteza, parece-me que, quando uma teoria torna-se muito coerente, perde sua função de pensamento; claro que ela serve para unir, mas não para pensar. A partir do momento em que cientistas, políticos, filósofos, etc. repetem e professam a mesma teoria, eles se adoram mutuamente, mas odeiam os que são adeptos de uma outra. A teoria assume uma função de clã e não mais de pensamento. Esse uso da teoria me parece muito perigoso, pois ela suprime o embate" (p. 52-53).

MORIN: “- No fundo, todo o problema reside nisso: a grande ameaça é o fechamento” (p. 92).
} 
por significarem restrição de direitos, não podem ficar sob a responsabilidade da doutrina e jurisprudência, cabendo ao legislador proceder à sua atualização com precisão e clareza.

O presente artigo é fruto de uma pesquisa qualitativa, essencialmente bibliográfica e documental, desenvolvida a partir do diálogo entre Direito de Família e Antropologia no que concerne à proibição do incesto e à definição de parentesco, objetos de estudo de ambas as ciências.

\section{DOS IMPEDIMENTOS MATRIMONIAIS}

Em regra, todas as pessoas possuem o direito natural para contrair matrimônio. Contudo, em algumas circunstâncias inspiradas no Direito Canônico, a legislação impõe restrições através dos denominados impedimentos matrimoniais. Através desta previsão legal o Estado determina que toda pessoa tem direito de casar, salvo aquelas taxativamente vedadas de contraírem o matrimônio, sendo que no caso de transposição desta barreira, desavisada ou deliberadamente pelos nubentes, o ordenamento jurídico sanciona as núpcias com decreto de nulidade absoluta (MADALENO, 2008, p. 80).

Segundo determina o art. 1.521 do Código Civil em vigor, não podem casar e, consequentemente, terem sua união estável ou homoafetiva reconhecida: I. Os ascendentes com os descendentes, seja o parentesco natural ou civil; II. Os afins em linha reta; III. O adotante com quem foi cônjuge do adotado e o adotado com quem o foi do adotante; IV. Os irmãos, unilaterais ou bilaterais, e demais colaterais, até o terceiro grau inclusive; V. O adotado, com o filho do adotante; VI. As pessoas casadas; VII. O cônjuge sobrevivente com o condenado por homicídio ou tentativa de homicídio contra o seu consorte.

A este estudo interessam apenas os impedimentos previstos nos incisos I ao V, todos decorrentes de relações de parentesco.

$\mathrm{O}$ inciso I refere-se à proibição do casamento entre ascendentes e descendentes, seja o parentesco natural ou civil, em grau infinito. Conforme explica o art. 1.593 do Código Civil, "o parentesco é natural ou civil, conforme resulte de consangüinidade ou outra origem". Esta última expressão que, tradicionalmente, referia-se ao parentesco oriundo da adoção, na atualidade, por força da doutrina e jurisprudência pátrias, precisa ser oxigenada de forma a abranger aquele decorrente da reprodução assistida heteróloga (envolvendo 
Laira Carone Rachid Domith

gametas de doadores) e da socioafetividade enquanto situação fática e espontânea fundada na "posse de estado" que não decorra das duas situações anteriores. Frise-se que a adoção faz com que o adotado se desligue completamente da família biológica, exceto com relação aos impedimentos matrimoniais (art. 41, Estatuto da Criança e do Adolescente).

Aqui, as razões do impedimento são de ordem moral - decorrentes da interdição do incesto - e eugênica, já que a proximidade genética entre os genitores pode acarretar problemas à saúde de sua prole. Contudo, conforme esclarece Panasco (1981, p. 19), o casamento endogâmico entre pessoas que possuem vínculo biológico próximo, por si só, não desencadeia problemas de saúde à sua descendência. Tais problemas dependem da imperfeição dos genes dos nubentes. Quando, no casamento consangüíneo, os genes são perfeitos em termos genéticos, a prole terá características satisfatórias.

O inciso II refere-se à proibição de casamento entre os afins em linha reta, ou seja, após o desfazimento de uma união anterior, ex-cônjuges ou ex-companheiros não poderão casar-se com os parentes do outro em linha reta, já que, nesta hipótese, a afinidade não se extingue com a dissolução do casamento ou da união estável (art. 1.595, § $2^{\circ}$, Código Civil). A proibição refere-se, pois, ao casamento entre sogra e genro, nora e sogro, madrasta e enteado, padrasto e enteada, pai do sogro e a nora e assim por diante.

Embora a lei não seja expressa neste sentido, Maluf e Maluf (2013, p. 135) ressaltam que "questão interessante é que o impedimento matrimonial resultante da afinidade veda apenas o casamento entre pessoas que integravam a unidade familiar à época em que o vínculo se dissolveu". Assim, não haverá parentesco por afinidade e, portanto, não subsistirá impedimento matrimonial entre uma mulher e os filhos de seu ex-marido tidos após a ruptura da união conjugal. Ressalte-se que se a união que deu origem à afinidade for declarada nula (através de ação declaratória) ou for anulada (ação anulatória) o impedimento deixará de existir.

O inciso III diz respeito à vedação do casamento entre o adotante e aquele que foi cônjuge do adotado e entre o adotado com aquele que tenha sido cônjuge do adotante. Gagliano e Pamplona Filho (2013, p. 226) explicam que "trata-se, em essência, de uma proibição análoga àquela imposta aos parentes por afinidade em linha reta", afigurando-se uma proibição de cunho moral.

O inciso IV veda o casamento entre irmãos bilaterais ou unilaterais, bem como entre colaterais até o terceiro grau, inclusive. Como o texto do artigo divide-se em duas 
partes, sua análise também será fracionada: segundo Diniz (2013, p. 86), o parentesco colateral em segundo grau compreende "os irmãos nascidos ou não de justas núpcias, os germanos ou bilaterais (que têm o mesmo pai e a mesma mãe), os unilaterais, sejam eles consangüíneos (nascidos do mesmo pai e de mães diversas) ou uterinos (que nasceram da mesma mãe e de pais diversos)". Aqui, o parentesco colateral de segundo grau de natureza civil não é mencionado e não é cabível a realização de interpretação extensiva neste sentido, já que a vontade do legislador foi abranger apenas o parentesco biológico. Prova disso foi que ele tratou, separadamente, no inciso $\mathrm{V}$, a vedação de casamento entre o adotado e o filho do adotante. Além desta vedação possuir cunho moral, tem como preocupação a saúde da prole eventual.

Com relação à segunda parte do inciso IV, importante ressaltar que o Decreto-Lei $\mathrm{n}^{\mathrm{o}}$. 3.200/1941 relativizou a proibição contida no mesmo ao permitir o casamento de tio(a) e sobrinha(o) desde que haja laudo médico atestando não haver perigo para a saúde da prole que advier desta união. A doutrina majoritária entende que o Código Civil de 2002 não revogou tal Decreto em razão do critério da lex specialis ${ }^{3}$. Desta forma, o impedimento somente subsistirá se houver prejuízo à saúde mental e física da prole eventual, não havendo cunho moral.

$\mathrm{O}$ inciso $\mathrm{V}$ veda o casamento entre o adotado e o filho do adotante. Insta salientar que, sob a égide do Código Civil de 1916, o inciso V do art. 183 determinava que o adotado só não poderia se casar com os filhos tidos pelo(s) adotante(s) após a adoção. Desta forma, o filho pré-existente à adoção poderia se casar com o filho adotivo, o que não é possível na atualidade.

“A adoção, no Código Civil de 2002, é concedida por sentença constitutiva (art. 1.623, parágrafo único), sendo, portanto, irretratável. O impedimento, em conseqüência, é perpétuo" (GONÇALVES, 2013, p. 76), desde que a adoção não venha a ser declarada nula

\footnotetext{
${ }^{3}$ Segundo Gonçalves, "O legislador de 2002 não se referiu à situação regulamentada pelo Decreto-Lei n. 3.200/41, que abria uma exceção à proibição legal de casamento entre tio e sobrinha, incorporada ao nosso sistema jurídico há mais de cinquenta anos. À primeira vista, ante a mencionada omissão, poder-se-ia entender vedado o casamento entre colaterais até o terceiro grau, e revogado o mencionado Decreto-Lei n. 3.300/41 pela lei posterior. Todavia, acabou prevalecendo a melhor interpretação doutrinária, no sentido de que a ideia da revogação da indigitada exceção afronta o princípio da especialidade. Com efeito o Decreto-Lei n. 3.400/41 é regra especial em relação ao Código Civil, pelo que sua disciplina se mantém íntegra. Não altera, portanto, o novo Código Civil o regime do casamento entre tios e sobrinhos: haverá vedação legal somente se comprovada a inconveniência das núpcias no que tange à saúde de futura prole" (2013, p. 73).
} 
Laira Carone Rachid Domith

ou seja anulada. Se o adotado ingressa na família do adotante como sendo seu filho, logicamente será considerado irmão do filho daquele que o adotou. Na verdade, esta conclusão poderia ser extraída do inciso IV do artigo em questão, já que o adotado terá parentesco colateral de segundo grau com o filho de seu adotante. Contudo, pelo fato de ter criado o inciso $\mathrm{V}$ especificando a vedação de casamento com o irmão adotivo, o legislador acabou deixando claro que o inciso IV refere-se ao parentesco colateral de segundo grau biológico, apenas, não englobando o parentesco colateral civil, do qual o parentesco adotivo é espécie. O impedimento, neste caso, é de ordem moral, já que na maioria absoluta dos casos não há proximidade genética entre o adotado e os filhos do adotante.

Ressalte-se, portanto, que a legislação em vigor veda apenas o matrimônio entre irmãos biológicos e adotivos, não impedindo expressamente o casamento entre os mesmos quando entre eles houver apenas vínculo socioafetivo de fato (posse de estado de irmãos).

\title{
2 DOS FUNDAMENTOS PARA A INTERDIÇÃO DO INCESTO
}

Conforme visto, a maioria dos impedimentos matrimoniais reside na interdição do incesto. Embora possa parecer que haja uma repulsa natural ${ }^{4}$ às relações incestuosas, necessário se faz que o Direito se debruce sobre a Antropologia e saiba um pouco mais sobre as origens daquela proibição para, a partir daí, abrir-se à reflexão acerca de tais restrições, já que

\begin{abstract}
(...) há nas leis, como nos tabus, a possibilidade do esquecimento de sua origem, ou da razão de sua promulgação; o que impede não só divergir das leis às quais todos estão submetidos como produz, não raro, uma obediência cega a essas leis sem que se discuta por que foram promulgadas e por que devemos respeitá-las. Essa cegueira já é o resultado de um recalque e tem como efeito, por sua vez, a mera obediência (ENDO, 2013, p. 21).
\end{abstract}

Assim, "a antropologia ensina ao jurista a existência, e a importância, do dado não verbalizado, presente no sistema” (SACCO, 2013, p. 18). “O antropólogo ensina o jurista a confrontar-se com modelos a que o jurista não prestou atenção até agora” (SACCO, 2013, p. 17) e "a construir um sistema racional e verídico das fontes" (SACCO, 2013, p. 19).

\footnotetext{
4 “A Igreja católica sempre foi hostil ao casamento entre parentes (...). Recorria-se à natureza, à lei natural (Santo Ambrósio, Santo Agostinho). Santo Agostinho procurou argumento que, sobre ser demasiado sutil, constituiu espécie de política das fusões, acima dos fundamentos religiosos e legais: o casamento semeia amor, liga; supérfluo, então, ligar pessoas que já estão ligadas e criar amor entre pessoas que já se amam" (MIRANDA, 2000, p. 256).
} 
A maior parte dos estudos sobre a interdição do incesto faz alusão à obra de Freud (1856-1939) e se desenvolve no campo da relação entre sociedade e cultura. Para este médico neurologista, considerado o pai da Psicanálise, o "horror ao incesto" situa-se no âmbito da sufocação das pulsões/impulsos e o desenvolvimento da cultura. Segundo explica Endo (2013, p. 19-23), Freud estudou a origem das proibições em “Totem e Tabu", observando o comportamento de vários tipos de povos primitivos:

Os tabus são definidos como obediência transmitida diante de certas proibições mantidas pela tribo, clã, grupo ou sociedade. Porém, Freud montava seu problema a partir da investigação sobre a suposição de sua origem: o totem. Para Freud, a fonte visível, dotada de força e autoridade sagrada e sobrenatural inquestionável, à qual todos os membros do mesmo clã deveriam temor, obediência e respeito é o totem. (...) Nesse mesmo sistema operam os tabus, prescrições e proibições dotadas de imensa força que determinam comportamentos sociais entre os que pertencem ao mesmo clã e que, obrigatoriamente, têm de professar as mesmas crenças e valores, vigiados pelos membros de seu próprio clã e, acima deles, pelo totem que os rege. Os tabus são proibições sem genealogia, isto é, eles determinam a obediência a seus preceitos sem que seja necessário, de modo algum, uma explicação sobre sua origem e força (sobrenatural). Freud viu nesses dois fenômenos, presentes, atuantes e interdependentes na cultura dos povos primitivos, dois elementos discutidos e trabalhados em profundidade na teoria e na clínica psicanalítica: a representação psíquica ambivalente do pai (totem) e o tabu do incesto como obediência e dívida inultrapassáveis a esse mesmo pai primevo. (...) Para Freud ficava claro, desde o princípio, que sujeito é cultura, e cultura constitui sujeitos. (...) Porém, a transmissão desses padrões assumidos pela cultura revela a preservação de mecanismos de esquecimento (repressão e recalque) que, por sua vez, induzem e produzem cultura. Dito de outro modo, a reprodução obediente aos tabus revela uma insistência que determina e marca as produções culturais de um povo que, por sua vez, se apóiam sobre a necessidade do esquecimento daquilo que produziu a proibição-tabu: o assassinato do pai. (...) A psicodinâmica desse processo revela que o assassinato do pai-tirano por seus filhos escravos foi acompanhado pela necessária organização entre esses filhos, organização que dependeu da aptidão no uso da linguagem, da experiência de desamparo e culpa que sucede o assassinato do pai ditador e provedor e por uma organização mínima, que deve incluir as regras de permissão e proibição sobre tudo aquilo que antes pertencia ao pai tirano e que, agora, está acessível a todos os irmãos assassinos. Portanto, o assassinato do pai tirano põe fim às crueldades e restrições por ele impostas, mas também ao seu papel protetor, provedor e líder, características do pai que os filhos veneravam e das quais dependiam. Entre essas restrições impostas pelo pai, ganha destaque a posse exclusiva das mulheres que, doravante, após o seu assassinato, passará a ser regulada pelo tabu do incesto. Não havendo mais o pai que determina e vigia a posse das mulheres, faz-se necessária uma regulação à qual todos deverão se submeter, tal como faziam com o pai tirano. Esse tabu projeta para fora do clã as alianças matrimoniais e proíbe o acesso dos homens às mulheres do mesmo clã, fundando a exogamia.

Explicando o totemismo adotado pelos aborígenes da Austrália, Freud relatou que uma espécie de animal, de planta ou um tipo de força da natureza (chuva, água...) se 
Laira Carone Rachid Domith

encontra em um patamar especial em determinado clã, sendo considerado o antepassado comum a todos os componentes do grupamento social. As obrigações sociais decorrem do pertencimento dos indivíduos a um totem específico, que relega a consanguinidade a segundo plano, podendo-se afirmar que o vínculo totêmico é, portanto, mais forte dos que os vínculos biológicos. Observou, ainda, a prescrição da exogamia vinculada ao totem, ou seja, os membros de um mesmo totem não podem manter relações sexuais ou contrair casamento entre si. Frise-se que

Visto que o totem é hereditário e não se modifica pelo casamento, é fácil ver as consequiências da proibição no caso da hereditariedade materna. Se o homem, por exemplo, pertence a um clã cujo totem é o canguru e se casa com uma mulher do totem emu, os filhos, tanto meninos quanto meninas, são todos emu. Pela regra totêmica, portanto, torna-se impossível a um filho desse casamento manter relações incestuosas com sua mãe e com suas irmãs, emu como ele.(...) Mas ao pai, que é canguru, se permite - pelo menos segundo essa proibição - o incesto com suas filhas, que são emu. No caso da herança paterna do totem, o pai seria canguru e os filhos também; o incesto com as filhas seria então proibido ao pai e o incesto com a mãe seria permitido ao filho (FREUD, 2013, p. 42).

“As proibições do tabu carecem de qualquer fundamentação; são de origem desconhecida; incompreensíveis para nós, parecem naturais para aqueles que se encontram sob seu domínio" (FREUD, 2013, p. 58-59); "eles não sabem por que e também não lhes ocorre perguntar a respeito, mas se submetem a elas como se fosse algo natural e estão convencidos de que uma transgressão será punida automaticamente da maneira mais dura" (FREUD, 2013, p. 62).

"Freud explica com êxito não o início da civilização, mas seu presente. Tendo partido à procura da origem de uma proibição, consegue explicar não por que o incesto é conscientemente condenado, mas como acontece que seja inconscientemente desejado" (LÉVI-SATRAUSS, 2009, p. 536). Neste contexto, pode-se afirmar que tanto o etnólogo quanto o psicanalista trabalhavam com o mesmo elemento (interdição do incesto), mas o primeiro no plano coletivo e o segundo no plano individual.

O desejo inconsciente da quebra do Tabu do Incesto demonstra que a repugnância ao mesmo não é algo inato. Lévi-Strauss crê que "a proibição do incesto explica-se inteiramente por causas sociológicas" (2009, p. 22) e que "persiste nas sociedades contemporâneas em forma de modelo mecânico" (2009, p. 33). Segundo Chinoy (2008, p. 217-218), 
As falhas das várias explicações da aparente universalidade do tabu do incesto apóiam uma explanação sociológica, que focaliza as funções do tabu do incesto na manutenção de uma estrutura social relativamente estável. A fim de persistir e exercer suas funções usuais, exige a família uma clara definição de papéis e relações em seu interior. As relações incestuosas lhe perturbariam seriamente a estrutura e interfeririam na sua continuada efetividade. Suponhamos que ocorressem relações entre pai e filha, por exemplo; quais seriam as relações apropriadas entre o filho de uma união dessa natureza e sua mãe e meia-irmã? De um modo geral, os filhos de uniões incestuosas ocupariam uma posição pouco clara e incerta em qualquer sistema familial, criando sérios problemas internos, capazes de destruir a estrutura. Além disso, as relações sexuais também propendem a ser incompatíveis com outras espécies de expectativas e obrigações mútuas. Num sistema matrilinear, em que o irmão da mãe fosse tabu, por exemplo, qual seria o efeito na autoridade normalmente exercida por um homem sobre a filha de sua irmã, se eles viessem a tornar-se sexualmente íntimos? Parece improvável que a combinação de intimidade sexual e relações de superioridade e autoridade pudesse ser institucionalizada por um período extenso qualquer.

Neste mesmo sentido, Malinowski, a partir de seu trabalho de campo realizado nas ilhas Trobriand na Nova Guiné,

(...) esforçou-se por defender uma concepção diferente, segundo a qual a proibição do incesto resultaria de uma contradição interna, no próprio seio da família biológica, entre sentimentos mutuamente incompatíveis, por exemplo, as emoções ligadas às relações sexuais e o amor pelos pais, ou "os sentimentos naturais que se travam entre irmãos e irmãs". Estes sentimentos, entretanto, só se tornam incompatíveis por motivo do papel cultural que a família biológica é levada a desempenhar. O homem tem de ensinar a seus filhos, e esta vocação social, exercendo-se naturalmente no meio do grupo familiar, estaria irremediavelmente comprometida se emoções de outro tipo viessem perturbar a disciplina indispensável à manutenção de uma ordem estável entre as gerações. "O incesto equivaleria à confusão das idades, à mistura das gerações, à desorganização dos sentimentos e a uma inversão brutal de todos os papéis, no momento exato em que a família representa um agente educativo de primeira importância" (MALINOWSKI apud LÉVI-STRAUSS, 2009, p. 529).

Em sentido oposto, Lévi-Strauss (2009, p. 530) explica, parafraseando Durkheim, que as relações incestuosas e os sentimentos familiares só parecem antagônicos porque a sociedade os concebeu como excludentes. Contudo, se a tradição permitisse ou estimulasse o casamento entre parentes próximos, a concepção de casamento seria totalmente diferente. Os impulsos sexuais teriam sido amortecidos, se aproximando dos sentimentos domésticos, sem que houvesse dificuldade em se conciliar com os mesmos. Exemplificando tal situação, relatos etnográficos de Means sobre os Chukchee, nativos dos Andes, demonstram que 
Laira Carone Rachid Domith

A idade das mulheres trocadas em casamento pouco é levada em consideração. Assim, no Rio Oloi, um homem chamado "QImIqäi casou seu filho, de cinco anos de idade, com uma moça de vinte anos. Em troca deu sua filha, que tinha doze anos, e esta casou-se com um jovem de mais de vinte anos. A mulher do menino desempenhava o papel de ama, dava-lhe de comer e punha-o na cama (...)". O autor cita também o caso de uma mulher casada com uma criancinha de dois anos, e que, tendo tido um filho de um "companheiro de casamento", isto é, de um amante oficial e temporário, dividia seus cuidados entre as duas criancinhas. "Quando dava de mamar a seu bebê, dava também de mamar a seu marido-bebê (...) e neste caso o pequeno marido tomava com satisfação o seio de sua mulher. Quando pedi que me explicassem o comportamento da mulher, o Chuchee respondeu: Quem sabe? Talvez seja um meio mágico para assegurar o futuro amor de seu jovem marido" (MEANS apud LÉVI-STRAUSS, 2009, p. 531).

Segundo explica Lévi-Strauss (2009, p. 534) "as regras do parentesco e do casamento não se tornaram necessárias pelo estado da sociedade. São o próprio estado da sociedade, remodelando as relações biológicas e os sentimentos naturais (...)". O autor refere-se à necessidade de estabelecimento de alianças em prol da sociabilidade e da organização da cultura, "já que cada relação familiar define um certo conjunto de direitos e deveres, e a ausência de relação familiar não define nada. Define a hostilidade” (2009, p. 525). "Se as duas famílias brigam e se insultam, dizem, isto não será sério, mas apenas uma questão de família, e a guerra será evitada” (2009, p. 524).

Observa-se que Lévi-Srauss "não se atém à família como grupo social concreto, a seus problemas específicos, mas ao que esta revela do mundo social, dentro da concepção estruturalista da sociedade como um sistema de relações" (SARTI, 2005, 32-33). Assim, a família consanguínea precisa ser desfeita para que a sociedade viva, pois na família construída a partir da aliança é possível ao ser humano se fazer social, comunicando-se e rompendo o isolamento imposto pela consanguinidade (SARTI, 2005, p. 33-34). "Para libertar-se de uma luta selvagem pela existência, confrontava-se com a escolha muito simples entre "casar fora" ou "morrer fora"” (LÉVI-STRAUSS, 1956, p. 326).

Desta forma, "a proibição do incesto é menos uma regra que proíbe casar-se com a mãe, a irmã ou a filha do que uma regra que obriga a dar a outrem a mãe, a irmã ou a filha. É a regra do dom ${ }^{5}$ por excelência" (LÉVI-STRAUSS, 2009, p 524-525). A interdição do

\footnotetext{
${ }^{5}$ Não se pode olvidar que Lévi-Strauss foi discípulo de Marcel Mauss, principal sistematizador da Teoria da Dádiva ou do Dom (dar - receber - retribuir) enquanto dinâmica de constituição de alianças. $\mathrm{O}$ autor realizou suas pesquisas na Polinésia, Melanésia e Noroeste americano numa época em que o mercado existia, mas antes da instituição dos mercadores e, principalmente, da moeda propriamente dita (MAUSS, 2003, p. 188). Observando os Maori, na Polinésia, percebeu que a coisa dada não é inerte, pois tende a retornar ao seu "lar de origem ou a produzir para o clã e o solo do qual surgiu um equivalente que a substitua" (MAUSS, 2003, p. 200). Tanto dar quanto o receber e o retribuir são obrigações. "Recusar dar, negligenciar convidar, assim como
} 
incesto pode ser descrita como a "oferta recíproca de uma "dádiva" - irmãs - que transforma os irmãos ofertantes em aliados, e as mulheres trocadas em vínculo da aliança" (BAUMAN, 2012, p. 232). Assim, a exogamia veda o casamento consanguíneo para prescrever o casamento com um grupo diferente da família biológica não pela existência de algum perigo biológico decorrente do casamento endógamo, mas porque do casamento exógamo resulta um benefício social (LÉVI-STRAUSS, 2009, p. 523-524). Conforme explica Lienhardt (1965, p. 122-123),

Cada família, ou unidade exógama maior, depende das mulheres que tem de conseguir fora, para a sua continuação. Uma condição preliminar da sociedade humana é a união e interdependência dessas unidades exógamas, união criada pelos casamentos e, portanto, pela sua regulamentação. (...) O incesto pode ser considerado, portanto, como um ato essencialmente anti-social. Nega a necessidade do grupo social mais amplo e tende a abolir as distinções fundamentais entre o homem e os animais inferiores, distinções que são valorizadas explicitamente, e talvez particularmente pelos povos para os quais a preservação de sua cultura especificamente humana exige uma luta árdua e constante contra as circunstâncias naturais.

Em outras palavras, “dá-se com o casal incestuoso o mesmo que com a família avara: Isola-se automaticamente do jogo que consiste em dar e em receber, ao qual se reduz toda a vida da tribo. Nesse corpo coletivo, tornam-se um membro morto ou paralisado" (DEVEREUX apud LÉVI-STRAUSS, 2009, p 532). Caso o incesto fosse uma prática comum, tais casamentos fariam com que o grupo social explodisse em uma multidão de famílias, formando vários sistemas fechados (LÉVI-STRAUSS, 2009, p 522).

Através da etnografia é possível perceber que as justificativas para a exogamia e a interdição do incesto variam entre os povos, mas possuem caráter funcional permanente e coextensivo a todos os grupos sociais. Partindo-se desta premissa, Lévi-Strauss (2009, p. 523) destaca que,

recusar receber, equivale a declarar guerra; é recusar a aliança e a comunhão" (MAUSS, 2003, p. 201-202). Por fim, conclui que "apesar da importância dessas trocas, como o grupo local e a família, noutros casos, são autosuficientes em matéria de ferramentas, etc., esses presentes não servem à mesma finalidade que o comércio e a troca nas sociedades mais desenvolvidas. A finalidade é antes de tudo moral, seu objeto é produzir um sentimento de amizade entre as duas pessoas envolvidas, e, se a operação não tivesse esse efeito, faltaria tudo..." (MAUSS, 2003, p. 211). Ressalte-se, ainda, que a troca não vale somente o que valem as coisas trocadas. A troca, e por conseguinte a regra de exogamia que a exprime, tem por si mesma um valor social" (LÉVI-STRAUSS, 2009, p. 523). 
Laira Carone Rachid Domith

Assim, as teorias de McLennan, de Spencer e de Lubbock têm, pelo menos, um sentido simbólico. Lembrando-nos que, quanto ao primeiro, a exogamia teria encontrado origem em tribos que praticavam o infanticídio das filhas, sendo, por conseguinte, obrigadas a procurar fora esposas para seus filhos. De maneira análoga, Spencer sugeriu que a exogamia deve ter começado entre tribos guerreiras, que raptavam mulheres nos grupos vizinhos. Lubbock apresentou a hipótese da oposição primitiva entre duas formas de casamento: o casamento endogâmico, no qual as esposas são consideradas propriedade comum dos homens do grupo, e o casamento exogâmico, que equipara as mulheres capturadas a uma espécie de propriedade individual do vencedor, dando assim nascimento ao casamento individual moderno.

Também através da etnografia observa-se que os impedimentos matrimoniais - as categorias de cônjuges possíveis (casamentos preferenciais e prescritivos) e a dos cônjuges proibidos - variam no espaço e no tempo. Conforme elucida Lévi-Strauss (2009, p. 46)

\begin{abstract}
Nosso eminente colega Ralph Linton observou-nos um dia que na genealogia de uma família nobre de Samoa, estudada por ele, (...) o casamento entre o irmão e a irmã mais velha aparece, pois, como uma concessão ao direito de primogenitura, e não exclui a proibição do incesto, porque, além da mãe e da filha, a irmã mais moça continua sendo um cônjuge proibido, ou pelo menos desaprovado. (...) Veremos adiante que os antigos japoneses descrevem o incesto como união com a irmã mais moça, sendo excluída a mais velha (...).
\end{abstract}

Nota-se, portanto, que "a proibição do incesto oferece o ponto de encontro mais evidente entre natureza e cultura: a natureza impõe a necessidade de aliança sem definir seu formato; a cultura determina sua modalidade" (BAUMAN, 2012, p. 232).

\title{
3 RESSIGNIFICAÇÃO DO PARENTESCO E DO INCESTO E SEUS REFLEXOS NO SISTEMA DE IMPEDIMENTOS MATRIMONIAIS
}

Até o presente momento este estudo dedicou-se à elucidação dos impedimentos matrimoniais que vigoram no Brasil e se fundamentam na interdição do incesto, bem como na demonstração do caráter cultural desta proibição nas mais diversas sociedades. Em outras palavras, se são de ordem cultural, podem variar, devendo acompanhar as mudanças sociais.

Não se pretende, aqui, contestar a existência da categoria dos impedimentos matrimoniais, mas adequá-los à atualidade, notadamente a partir do aumento da realização da reprodução assistida heteróloga (envolvendo gametas de doadores) e do reconhecimento doutrinário e jurisprudencial da socioafetividade. A partir daí chegar-se-á à desconstrução do conceito tradicional de incesto, atualizando-o. Se a proibição do incesto é universal, os conceitos de parentesco, filiação, maternidade e paternidade não desfrutam desta mesma 
prerrogativa. Se, tradicionalmente, o conceito de parentesco desenvolveu-se a partir dos pares dicotômicos natureza/cultura e dado/construído, há que se pensar sobre a noção de "dado" e de "natureza" na atualidade em que a genealogia não é a tradução de um sistema universal de parentesco.

Conforme destaca Héritier, o estudo do parentesco é o domínio por excelência da Antropologia. Embora ao cidadão comum sejam muito familiares os termos "família", "casamento" e "parentesco", tal familiaridade decorre de suas memórias de como os mesmos se apresentam em seu cotidiano, na sociedade em que está inserido. Contudo, este pensamento falseia o verdadeiro significado das referidas significantes. Para a autora,

\begin{abstract}
Entrar no domínio do parentesco significa entrar numa esfera de estranheza: um velho chama a uma rapariga "mãe"; um homem que goza de consideração geral pode casar-se com a filha do irmão da sua mãe, mas é considerado o mais miserável dos seres, expulso, talvez espancado, ou condenado à morte, se tiver relações suspeitas com a filha do irmão do seu pai, ou até com a neta do irmão do seu avô paterno; uma mulher brinca livremente com o irmão mais novo do seu marido, injuriando-o com termos obscenos, mas baixa humildemente os olhos perante o irmão mais velho, a quem serve de joelhos e a quem nem sequer dirige a palavra...Tudo isso não significa, no entanto, entrar no reino de um total arbítrio. Os conjuntos diferentes dos nossos, elaborados por outras sociedades, funcionam de modo equilibrado (...) e encontram intelectualmente justificação aos olhos dos seus próprios membros $(1989$, p. 27).
\end{abstract}

Para refletir sobre o parentesco no Brasil da atualidade, é imperioso que se trace um breve panorama sobre como as famílias se apresentam neste mesmo contexto. Considerando que a legislação pátria não acompanhou suas transformações, pode-se dizer que o conceito mais atual de família, extraído da fundamentação de acórdãos de tribunais superiores, fundase na "vontade de constituir família", averiguada a partir da verificação fática da "posse de estado" (leia-se "agir como se fosse e receber tratamento como se fosse") de companheiro, de pai, de mãe, de filho(a), de irmão(ã), revestida pelos requisitos da reciprocidade, publicidade e durabilidade. Foi com base em tais critérios que as uniões estáveis foram reconhecidas, as uniões homoafetivas, as uniões paralelas e o parentesco socioafetivo, sendo elemento fundamental às famílias multiparentais e multiespécie.

Ainda que a vontade de constituir família seja um requisito constitutivo dos vínculos socioafetivos, nos vínculos consaguíneos e de afinidade se apresenta na forma de um aspecto desejável, construindo relações familiares mais sólidas e sadias e indo, portanto, 
Laira Carone Rachid Domith

ao encontro da concretização da função social da família, qual seja, a proteção e promoção da dignidade de seus membros. Conforme ressalta Perlingieri (2002, p. 244).

O sangue e os afetos são razões autônomas de justificação para o momento constitutivo da família, mas o perfil consensual e a affectio ${ }^{6}$ constante e espontânea exercem cada vez mais o papel de denominador comum de qualquer núcleo familiar. $\mathrm{O}$ merecimento de tutela da família não diz respeito exclusivamente às relações de sangue, mas, sobretudo, àquelas afetivas que se traduzem em uma comunhão espiritual e de vida.

Em contraposição à vontade de constituir família, assiste-se, também, à vontade de deixar de ser família, através da facilitação do divórcio, da dissolução das uniões estáveis, da entrega de filhos para a adoção, e da polêmica adoção do maior de dezoito anos que não precisa do consentimento da família de origem para dela se desligar permanentemente através de uma ação de adoção. Essa valorização da vontade demonstra que "a nova disciplina jurídica da família merece menos clausura e mais libertação" (FACHIN, 1996, p. 20), ou seja, menos nó e mais ninho (PERROT, 1993, p. 74-81), este traduzindo a ideia de aconchego, proteção, segurança, refúgio, abrigo.

Embora esta conceituação de parentesco como vontade de constituir família possa parecer revolucionária na atualidade, já era defendida desde os anos 70 pelos movimentos comunitários surgidos na França e nos Estados Unidos. Relatando este contexto, André-Jean Arnaud, jurista francês, especialista em história do pensamento jurídico e político, destaca que entre os anos de 1968 e 1972 iniciou-se o período de transformação legal da instituição familiar na França, impulsionada pelo fato de um grande número de jovens, julgando uma aberração a vida cotidiana do mundo ocidental, insurgindo-se contra os estatutos sociais e as relações estatutárias legalmente estabelecidas, decidiu retirar-se da sociedade e viver em comunidades/colônias. Especificamente quanto às relações familiares, aqueles jovens criticavam o fato de o homem ser considerado detentor de direitos e poderes sobre sua família. Recusavam a família dada pelo sangue e entendiam que uma família deveria ser escolhida, surgindo, a partir daí, a noção de comunidade fundada em laços de parentesco socioafetivo. As comunidades eram reagrupamentos sociais organizados por afinidades. Eram as verdadeiras famílias, formadas não por facilidade, mas para romper precisamente com a instituição do casal e da família tradicional (ARNAUD, 1991, p. 119-139).

\footnotetext{
${ }^{6}$ Affectio familiae significa ânimo de constituir família.
} 
No mesmo sentido, Weston (2003, p. 58), relatando suas pesquisas realizadas na década de 80 em São Francisco (Estados Unidos), apresenta a "família eleita" ou "família gay" que, em oposição à tradicional família biológica e heterossexual, se formava a partir da incorporação de amigos, amantes, filhos, em quaisquer combinações, fundadas na ideologia do amor, da escolha e da criatividade. Este tipo de família surgiu como conseqüência do forte apelo do movimento gay para que os homossexuais assumissem esta condição publicamente na década de 70. Neste contexto, gays e lésbicas eram reduzidos à sua identidade sexual, esta ao sexo propriamente dito e este à promiscuidade. Assim,

\begin{abstract}
Declararse homosexual ante un familiar biológico ponía a prueba el amor incondicional y la solidariedad duradera comúnmente atribuidos en Estados Unidos a los vínculos familiares. En las historias sobre la salida del armario ante un familiar, la "aceptación" se correspondía con una confirmación explícita del amor y el parentesco. El "rechazo", en cambio, podía conllevar la ruptura de lazos de familia hasta entonces considerados inalienables. En este sentido, la revelación ante un familiar biológico produce un discurso destinado a revelar la "verdad" no solamente acerca de la persona, sino acerca de sus relaciones de parentesco (WESTON, 2003, p. 78).
\end{abstract}

As famílias de eleição foram, portanto, um refúgio construído pelos homossexuais renegados por suas famílias de origem, expondo o fato de que o vínculo biológico não era suficiente para determinar e fazer perdurar o parentesco (WESTON, 2003, p. 16). Assim, o vínculo biológico seria tão simbólico quanto o elegido ou criado (WESTON, 2003, p. 68), o que reabilitou o conceito de parentesco para a investigação antropológica: o parentesco começou a parecer mais um problema de esforço e eleição do que um vínculo permanente, já que, em alguma situações, o sangue se apresentava mais ralo que a água (WESTON, 2003, p. 68).

A eleição do parentesco expandiu a noção de família para além do casal e dos filhos (WESTON, 2003, p. 20) e contribuiu para a politização do parentesco nos Estados Unidos, pois serviu como mote para o debate sobre as técnicas de reprodução assistida, a maternidade substituta, a adoção, o aborto, o crescente número de mães solteiras e de famílias reconstituídas após processos anteriores de divórcio, misturando filhos da antiga e da atual união (WESTON, 2003, p. 26). Dentro deste contexto, paradoxalmente, o baby boom lésbico representou a reincorporação do elemento biológico às famílias de eleição (WESTON, 2003, p. 49), demonstrando que estas não eram contra o modelo biológico, mas 
Laira Carone Rachid Domith

que a sociedade não poderia se restringir a ele; não se tratando, portanto, de justaposição, mas de adição ${ }^{7}$.

Neste sentido, faz-se mister a apresentação dos estudos etnográficos realizados na década de 80 por Carsten (1995) com os malaios de Pulau Langkawi, para os quais o parentesco é um processo de tornar-se que ocorre através de ações e dos corpos das mulheres: crianças são produzidas a partir de suas mães de sangue; suas mães de leite podem ativar ou criar parentesco; e a comida cozinhada na lareira pelas mulheres não apenas nutre fisicamente, mas cria laços emocionais centrais para o processo de conectividade. Assim, as ideias sobre parentesco são expressadas em termos de procriação, alimentação e aquisição de substância. Para este povo não há distinção entre "fatos de biologia" (nascimento) e "fatos de sociabilidade" (comensalidade). Sangue, leite e arroz são similares e equivalentes em termos de produção de parentesco. O compartilhamento de qualquer um ou todos estes elementos significa que as pessoas possuem substância comum ${ }^{8}$.

Uma curiosidade importante é que a amamentação define a categoria de relações incestuosas: os que se alimentam em uma mesma casa podem se casar, mas não poderão fazê-lo os que tiveram a mesma mãe de leite. O irmão mais velho frequentemente tem relações amorosas com as irmãs mais jovens, o que possui um significado estrutural, já que ele fornece a elas um modelo para a relação entre marido e esposa. Esta prática não é obrigatória e pode ser evitada, mas captura o ideal de afeto, igualdade, e respeito no qual o casamento deveria se basear.

O sangue não é simplesmente uma substância que nasce com o indivíduo. Ele é continuamente produzido a partir das refeições que a pessoa faz. O compartilhamento da alimentação é substancial para a definição de irmandade e começa no útero. Em sua primeira casa (útero) a criança é nutrida por sua mãe de sangue. Depois do nascimento, o bebê é

\footnotetext{
${ }^{7}$ Esta justaposição pode ser percebida no Xangô do Recife. Nos cultos Xangô de tradição Nagô, "como uma unidade social, a família de santo coloca ao alcance dos seus membros um sistema de parentesco alternativo que é organizado e estável, apesar de ser bastante esquemático, o que libera as pessoas da incerteza de terem que depender unicamente da cooperação e solidariedade das relações de parentesco legítimo (...). A família de santo simula uma família afro-americana simples e inteiramente confiável, já que se apóia em sanções sobrenaturais e é ritualmente legitimada. Em alguns casos, quando o membro provém de uma família bem constituída nos termos da ideologia dominante na sociedade brasileira, a família de santo funciona como uma extensão daquela, ampliando a rede de pessoas que podem ser chamadas a ajudar em caso de necessidade (SEGATO, 1986, p. 30).

8 "A sociabilidade faz a casa, em vez de ser a casa, o centro, - que reúne e associa. (...) A causa é a semelhança. Encontramo-la nos próprios agregados heterogêneos, porque é elemento comum que associa" (MIRANDA, 2000, p. 198).
} 
alimentado por sua mãe de leite. Pessoalidade e parentesco são derivados de um processo cotidiano de convivência onde as pessoas que se relacionam e se alimentam juntas tornam-se parentes a partir destas relações. Assim, mulheres e lareiras produzem parentesco.

Carsten (2000), a partir de seus estudos de campo com filhos adotivos realizados no oeste da Grã-Bretanha, constatando que a adoção desmonta, desconstrói o biológico e constrói o social, propõe uma reflexão acerca da redefinição de parentesco numa perspectiva mais aberta e flexível, no sentido de que o mesmo vai muito além do parentesco biológico.

É seguindo esta diretriz de valorização de vínculos sociafetivos, construídos no diaa-dia a partir da vontade recíproca de constituir família, que passar-se-á à reflexão sobre o conceito de incesto na atualidade e dos impedimentos matrimoniais nele fundados, sendo certo que as indagações resultantes desta problematização serão mais um ponto de partida para a reflexão crítica de tal instituto jurídico do que problemas de pesquisa aos quais se busca uma resposta.

Tomando como exemplo o casamento entre a filha biológica e o filho de criação da falecida cantora norte-americana Whitney Houston indaga-se se, caso o mesmo ocorresse no Brasil, o fato de não ter havido adoção formalizada através de ação judicial afastaria a incidência de impedimento matrimonial. A sentença de adoção teria o condão de conferir imoralidade ao casamento entre irmãos adotivos, não subsistindo julgamento moral no caso da união entre irmãos de criação? Indo mais além, sabe-se que o filho adotivo não pode casar-se com os pais adotivos, mas a situação mudaria de figura de fosse apenas filho de criação?

"Muito se questiona se a lei civil enlaçou o critério socioafetivo. Como bem observa Sérgio Gischkow Pereira, tudo indica que o legislador dele não cogitou. A doutrina e a jurisprudência vêm se esforçando por detectá-lo" (DIAS, 2009, p. 315). Assim, como a lei brasileira não prevê expressamente o parentesco socioafetivo, poder-se-ia lançar mão dos recursos da interpretação extensiva ou da analogia para restringir direitos de pessoas que desejam contrair casamento?

Segundo caso: diante de adoção de maior de dezoito anos, caso este(a) inicie um relacionamento amoroso com um dos membros da família adotiva (pai, mãe, irmão(ã)) assim que nela ingressar, sem que tenha havido tempo para a construção do vínculo socioafetivo 
Laira Carone Rachid Domith entre eles, subsiste o impedimento matrimonial? Partindo-se da premissa de que a adoção é irrevogável, a sentença de adoção deveria se sobrepor à inexistência do sentimento de parentesco e à existência do sentimento amoroso?

Terceiro caso: Diante da reprodução assistida $^{9}$ heteróloga, realizada a partir da utilização de gametas de doadores, a relação de ascendência-descendência puramente biológica entre doador(a) e aquele que nasceu da utilização de seu material genético geraria impedimento matrimonial? Em outras palavras, o impedimento subsistiria mesmo que o ascendente genético não possa ser considerado pai/mãe? Ainda neste contexto, estariam impedidos para o casamento os descendentes de um mesmo doador de gametas, sendo certo que não são irmãos, apenas indivíduos geneticamente próximos? Em ambos os casos, haveria impedimento de caráter moral, mesmo sem que nunca tenha havido relação de parentesco entre eles? Com relação à preocupação com a saúde da prole eventualmente advinda destas uniões, decorrente da proximidade genética desses indivíduos, poderia ser resolvida através de seleção embrionária e da terapia gênica, procedimentos possibilitados pela reprodução assistida.

Ainda no contexto da reprodução assistida ${ }^{10}$, especificamente com relação à gestação de substituição, considerando que a geratriz deve ter parentesco consangüíneo até o $4^{\mathrm{o}}$. grau com os autores do projeto parental ou receber autorização do Conselho Regional de Medicina para desempenhar tal função, subsiste impedimento para que a mesma contraia união com a criança por ela gerada e parida, ainda que não se enquadre nas hipóteses de impedimento atualmente previstas no art. 1.521 do Código Civil?

Tais questionamentos práticos, por si só, fazem com que fique muito clara a desatualização da legislação pátria no que diz respeito aos impedimentos matrimoniais e colocam em xeque os fundamentos para a previsão de tais restrições.

\footnotetext{
${ }^{9}$ Ver Resolução no $2.121 / 2015$ do Conselho Federal de Medina.

${ }^{10}$ Em artigo escrito em 2009, Strathern, comentando o aniversário de 40 anos de um artigo sobre reprodução assistida publicado na revista inglesa Nature, destaca que, "repentinamente, as pessoas estavam discutindo o que constituía a maternidade e a paternidade, preocupando-se com quem era a mãe ou o pai "real", debatendo a relação entre natureza e criação, e, acima de tudo, talvez tornando familiar o que era algo como um segredo profissional entre antropólogos, que as relações sociais e as biológicas podiam ser separadas por oferecerem distintos modos de consideração" (2009, p. 19). (...) "Como sabemos, uma articulação que a TRA explicitou - o que os euro-americanos viam antes como um nexo de eventos naturais - coito, concepção e nascimento - foi fragorosamente desarticulada na prática. A desarticulação na prática também torna mais fácil a desarticulação no pensamento" (2009, p. 30).
} 


\section{CONSIDERAÇÕES FINAIS}

O objetivo do presente estudo foi elucidar os impedimentos matrimoniais fundados no Tabu do Incesto - que também são determinantes para o reconhecimento das uniões estáveis e homoafetivas - com o intuito de denunciar sua desatualização diante da desbiologização do parentesco.

Uma pseudo sensação de que a universalidade da interdição do incesto funda-se tanto na natureza quanto no fundamento moral comum da sociedade constrói um engenho de negação do diferente e esta negativa e marginalização de situações menos totalizantes está carregada de anacronismos, reducionismos e vícios metodológicos. É imperioso que o arcabouço legislativo não funcione como calabouço ideológico ${ }^{11} \mathrm{e}$, por este motivo, estudos etnográficos de vários antropólogos foram citados para desmistificar o Tabu do Incesto.

Para repensar o que é incesto na atualidade, foi fundamental revisitar o conceito de família e perceber que esta precisa ser percebida para além dos vínculos consaguíneos e de afinidade, já que se assiste ao esvaziamento do conceito de parentesco ligado à genealogia e à reordenação dos símbolos de parentesco.

\footnotetext{
11 "Estar localizado na sociedade significa estar no ponto de interseção de forças sociais específicas. Geralmente quem ignora essas forças age com risco. (...) As instituições trazem consigo um princípio de inércia, talvez alicerçada, em última instância, na estupidez humana. (...) Nos níveis ocupados pela maioria dos homens, inclusive o autor e (supomos) quase todos os leitores destas linhas, a localização na sociedade constitui uma definição de regras que têm de ser obedecidas. Como vimos, o consenso geral da sociedade entende isto. $\mathrm{O}$ sociólogo não contradiz esse entendimento. Ele o aguça, analisa suas raízes, às vezes o modifica ou o amplia. Veremos mais tarde que a perspectiva sociológica finalmente ultrapassa o consenso geral do "sistema" e de nosso cativeiro nele" (BERGER, 1986, p. 79-80).
} 
Laira Carone Rachid Domith

O genuíno ânimo de constituir família associado à "posse de estado" de membro deste núcleo familiar constrói a família de fato, a família efetiva, a denominada família socioafetiva. A partir dos tradicionais pares antagônicos natureza/cultura e dado/construído, buscou-se demonstrar que consanguinidade/socioafetividade não se justapõem, necessariamente, podendo coexistir numa operação de adição.

De todo o relatado, chega-se à conclusão de que "toda sociedade procura acondicionar a forma de família às suas necessidades" (PERROT, 1993, p. 75), sendo certo que o parentesco e a definição das relações incestuosas seguem esta mesma dinâmica. Portanto, constata-se que a verdade sobre a família, o casamento, o parentesco e a proibição do incesto foi inventada e que, segundo Foucault (2005, p. 142), "é preciso destruir a vontade de verdade" ${ }^{\prime 2}$.

\footnotetext{
12 "A fragmentação e a heterogeneidade das sociedades contemporâneas fazem com que suas práticas não possam mais ser legitimadas por metanarrativas abrangentes e pretendendo totalizar o conjunto da experiência humana. O pós moderno é pensado então como "incredulidade em relação às metanarrativas", e produz-se enquanto uma crise que atinge os discursos e as expressões artísticas e culturais que se pretendem universais, unificadoras do conjunto da experiência de uma humanidade em geral. (...) a crise das "metanarrativas de legitimação" eclodiu como parte da emergência da problemática do outro, ou seja, dos movimentos de afirmação de identidades raciais, étnicas, sexuais, locais, etc que identificam nos discursos derivados da concepção iluminista de razão universal a dominação empírica de uma razão branca, masculina, burguesa e ocidental" (VAITSMAN, 1994, p. 21).
} 


\section{REFERÊNCIAS}

ARNAUD, André-Jean. A importância da utopia comunitária dos anos 70 para o estudo do direito de família contemporâneo. In: $O$ direito traído pela filosofia. Tradução de Wanda de Lemos Capeller e Luciano Oliveira. Porto alegre: Sérgio Antônio Fabris Editor, 1991, p. 119-139.

BAUMAN, Zygmunt. Ensaios sobre o conceito de cultura. Tradução de Carlos Alberto Medeiros. Rio de Janeiro: Zahar, 2012.

BERGER, Peter Ludwig. Perspectivas sociológicas: uma visão humanística. 25a . Ed. Tradução de Donaldson M. Garschagen. Petrópolis: Vozes, 1986.

CARSTEN, Janet. The substance of kinship and the heat on the hearth: feeding, personhood, and relatedness among Malays in Pulau Langkawi. In: American Ethnologist, v. 22, 1995, p. 223-241. Disponível em: http://www.academicroom.com/article/substance-kinship-and-heat-hearth-feedingpersonhood-and-relatedness-among-malays-pulau-langkawi. Acesso em 13/10/2014.

Knowing where you've come from: ruptures and continuities of time and kinship in narratives of adoption reunions. In: Journal of the Royal Anthropological Institute. Vol. 6, issue 4, december/2000, p. 577-779. Disponível em: http://onlinelibrary.wiley.com/doi/10.1111/14679655.00040/pdf. Acesso em 06/06/2014.

CHINOY, Ely. Sociedade: uma introdução à sociologia. 20a. Ed. Tradução de Octavio Mendes cajado. São Paulo: Cultrix, 2008.

CYRULNIK, Boris; MORIN, Edgar. Diálogo sobre a natureza humana. Tradução de Edgard de Assis Carvalho. São Paulo: Palas Athena, 2012.

DIAS, Maria Berenice. Manual de direito das famílias. $5^{\text {a }}$ Ed. rev. atual. e ampl. São Paulo: Editora Revista dos Tribunais, 2009.

DINIZ, Maria Helena. Curso de direito civil brasileiro, volume 5: direito de família. 28a. Ed. São Paulo: Saraiva, 2013.

ENDO, Paulo. Totem e tabu e a psicanálise além de suas próprias fronteiras. In: FREUD, Sigmund. Totem e tabu: algumas correspondências entre a vida psíquica dos selvagens e a dos neuróticos. Tradução de Renato Zwick; revisão técnica e prefácio de Paulo Endo. Porto Alegre: L\&PM, 2013, p. $17-28$. 
FACHIN, Luiz Edson. Da paternidade - relação biológica e afetiva. Belo Horizonte: Del Rey, 1996.

FREUD, Sigmund. Totem e tabu: algumas correspondências entre a vida psíquica dos selvagens e a dos neuróticos. Tradução de Renato Zwick; revisão técnica e prefácio de Paulo Endo. Porto Alegre: L\&PM, 2013.

FOUCAULT, Michel. A verdade e as formas jurídicas. Tradução de Roberto Machado et al. Rio de Janeiro: Editora Nau, 2005.

GAGLIANO, Pablo Stolze; PAMPLONA FILHO, Rodolfo. Novo curso de direito civil, volume 6: direito de família. $3^{\text {a }}$. Ed. rev. atual e ampl. São Paulo: Saraiva, 2013.

GONÇALVES, Carlos Roberto. Direito civil brasileiro, volume 6: direito de família. 10ª . Ed. São Paulo: Saraiva, 2013.

HÉRITIER, Françoise. Parentesco. Tradução de Magda Bigotte de Figueiredo. In: Enciclopédia Einaudi, vol. 20. Lisboa: Imprensa Nacional - Casa da Moeda, 1989, p. 27-79. Disponível em: https://classicos12011.files.wordpress.com/2011/03/51686748-enciclopedia-einaudi-parentescoparte-11.pdf. Acesso em: 02/08/2015.

LÉVI-STRAUSS, Claude. A família. In: SHAPIRO, Harry L. (Org.). Homem, cultura e sociedade. São Paulo: Fundo de Cultura, 1956, p. 308.

As estruturas elementares do parentesco. Tradução de Mariano Ferreira. $5^{\text {a }}$.ed. Petrópolis: Vozes, 2009.

LIENHARDT, Godfrey. Antropologia Social. Tradução de Waltensir Dutra. Revisão de Otávio Guilherme Velho. Rio de Janeiro: Zahar, 1965.

MADALENO, Rolf. Curso de Direito de Família. Rio de Janeiro: Forense, 2008.

MALUF, Adriana Caldas do Rego Freitas Dabus; MALUF, Carlos Alberto Dabus. Curso de Direito de Família. São Paulo: Saraiva: 2013.

MAUSS, Marcel. Sociologia e antropologia. Tradução de Paulo Neves. São Paulo: Cosac Naify, 2003.

MIRANDA, Ponde de. Tratado de direito privado, tomo 7. Campinas: Bookseller, 2000.

PANASCO, Wanderby Lacerda. Anulação do casamento e divórcio: aspectos médico-legais. Rio de Janeiro: Forense, 1981.

PERLINGIERI, Pietro. Perfis do direito civil - introdução ao direito civil-constitucional. Tradução de Maria Cristina De Cicco. 2a . Ed. Rio de Janeiro: Renovar, 2002.

PERROT, Michelle. O nó e o ninho. In: HARAZIN, D. (Org.). Veja 25 anos - reflexões para o futuro. São Paulo: Abril, 1993, pp. 74-81.

SACCO, Rodolfo. Antropologia jurídica: contribuição para uma macro-história do direito. São Paulo: Martins Fontes, 2013. 
SARTI, Cyntia Andersen. "Deixarás pai e mãe": notas sobre Lévi-Strauss e a família. In: Revista Anthropológicas, ano 9, v. 16, Recife, 2005, p. 31-52.

SATRATHERN, Marilyn. A antropologia e o advento da fertilização in vitro no Reino Unido: uma história curta. In: Cadernos Pagu, n. 33, Campinas, julho/dezembro 2009, p. 9-55. Disponível em: http://www.scielo.br/pdf/cpa/n33/02.pdf. Acesso em: 08/08/2015.

SEGATO, Rita Laura. Inventando a natureza: família sexo e Gênero no Xangô do Recife. In: Anuário Antropológico 85. Rio de Janeiro: Tempo Brasileiro, 1986.

VAITSMAN, Jeni. Flexíveis e plurais - identidade, casamento e família em circunstâncias pósmodernas. Rio de Janeiro: Rocco, 1994.

WESTON, Kath. Las famílias que elegimos - lesbianas, gays y parentesco. Bellaterra: Barcelona, 2003. 